\title{
Immigration and product diversity
}

\author{
Francesca Mazzolari • David Neumark
}

Received: 24 September 2009 / Accepted: 17 January 2011 /

Published online: 12 February 2011

(C) The Author(s) 2011. This article is published with open access at Springerlink.com

\begin{abstract}
We study the effects of immigration on the diversity of consumption choices. Data from California in the 1990s indicate that immigration is associated with fewer stand-alone retail stores and a greater number of large and in particular big-box retailers-evidence that likely contradicts a diversityenhancing effect of immigration. In contrast, focusing on the restaurant sector for which we can better identify the types of products consumed by customers, we find that immigration is associated with increased ethnic diversity of restaurants. This latter effect appears to come in part from the comparative advantage of immigrants in the production of ethnic goods.
\end{abstract}

Responsible editor: Klaus F. Zimmermann

Electronic supplementary material The online version of this article (doi:10.1007/s00148-011-0355-y) contains supplementary material, which is available to authorized users.

F. Mazzolari

Centro Studi Confindustria, viale dell'Astronomia 30, 00144 Rome, Italy

F. Mazzolari · D. Neumark

IZA, Bonn, Germany

D. Neumark $(\bowtie)$

Department of Economics, University of California, Irvine, 3151 Social Science Plaza, Irvine, CA 92697, USA

e-mail:dneumark@uci.edu

D. Neumark

NBER, Cambridge, MA, USA

D. Neumark

Public Policy Institute of California, San Francisco, CA, USA 
Keywords Immigration $\cdot$ Product diversity

JEL Classification J61 $\cdot \mathrm{F} 16$

\section{Introduction}

The share of foreign-born workers in the US labor force increased from $6.5 \%$ in 1980 to $13.3 \%$ in 2007 . Contemporaneous with the remarkable surge in immigration, a controversial debate has arisen on the economic consequences of immigration-in large part focused on whether immigrants compete with natives for jobs and hence reduce wages for US workers. Economic theory can be readily used to justify concerns over the effects of immigrant inflows on outcomes for natives who compete with immigrants for similar jobs (see, e.g., Borjas 2009; Davis and Weinstein 2002), and an extensive empirical literature assesses these effects.

A much less studied question is the effect of immigration on the variety of consumption choices in the destination country. Because immigrants are consumers with potentially different demand characteristics and also may have a comparative advantage in the production of ethnic goods, their arrival may change the composition of products available to consumers. The sign of the effect of immigration on product diversity, which can result from both output demand and labor supply shifts, is ambiguous. To the extent that immigrants have higher price elasticities of demand and/or less attachment to brands, they may increase demand for low-cost, standardized goods such as those often thought to be offered by big-box retailers, potentially reducing diversity in consumption choices. On the other hand, because of the differentiated variety of products that immigrants consume and produce, an inflow of foreign-born individuals may increase the diversity of consumption choices available to natives in non-tradable services, such as retail trade and restaurants. Our research attempts to quantify some of these "composition/variety" effectswhich have been often mentioned in the immigration literature but hardly ever modeled or measured.

To investigate the effects of immigration on product diversity, we focus on small areas that experienced different immigration inflows. The immigrant inflows would only be expected to have effects on local markets for goods and services that are locally produced and non-traded; hence, our focus is on these non-tradable sectors, in particular the retail trade and the restaurant sector. ${ }^{1}$ We use data from the National Establishment Time Series (NETS) database

\footnotetext{
${ }^{1}$ The proportion of goods and services consumed by immigrants might be too small to affect the product demand curve for nationally-traded goods ("traded"); and goods that are traded nationally may also be traded internationally, so immigration does not necessarily change the demand or supply of these goods. Regardless, our identification strategy focuses on local markets, and it is not clear how one would identify the effects on national markets.
} 
matched with Census of Population data. The NETS covers essentially all establishments, and provides detailed information on both geographical location and industry. We use NETS data for the entire state of California, mapping each business establishment in the NETS to its Census tract and merging the NETS data with Census of Population data on changes in the total and foreignborn population residing in each tract. California is an immigrant-rich area; in 2000 , the state was home to one third of all foreign-born individuals living in the USA. Our empirical evidence is based on the relationships between immigrant inflows into local areas and a number of dimensions of change in the employment and composition of businesses in these local areas. Strictly speaking, then, we do not measure output but infer the effects of immigration on the composition of output from changes in the composition of employment and businesses.

\section{Prior research on the effects of immigration on product variety}

In contrast to the extensive literature on immigration and natives' labor outcomes, there is far less work that investigates how immigration changes product diversity. There is, in fact, relatively little work that even tries to measure product demand shifts associated with immigration (Borjas 2009, footnote 8) or effects of immigration on prices, which might be viewed as prerequisites for immigration to have much effect on product diversity. As such, we start by briefly reviewing the available evidence on product demand shifts and price effects.

Using store-level price data, Lach (2007) finds a large and significant reduction in prices following the unexpected arrival of a large number of immigrants from the former Soviet Union in Israel during 1990. The shortrun nature of the empirical analysis - restricted to changes in prices in 1990 limits the extent to which the negative immigration effect can be explained by declines in retail costs stemming from an outward labor supply shift, and in fact the immigration-induced labor supply shocks were arguably small in light of the low labor force participation of the recently arrived immigrants. If interpreted as demand-side effects, Lach's results are consistent with new consumers having higher price elasticities and lower search costs than the native population. In addition, evidence for prices for different product categories is consistent with product demand shifts induced by immigration, as prices increased more for products representing a relatively larger share of expenditures for immigrants.

Bodvarsson et al. (2008) analyze the effects of the inflow of Cuban immigrants into Miami after the Mariel Boatlift of 1980. They find a positive and significant impact of immigrant inflows on retail sales per capita, and interpret their findings as evidence of positive consumer demand effects. Finally, the study of Bodvarsson and Van den Berg (2006) of Hispanic immigration to Dawson County, Nebraska-a uniquely segmented economy where immigrants work exclusively in an export sector (the meatpacking industry) but, as 
usual, consume locally—also suggests that immigration can substantially boost local consumer demand.

Evidence consistent with the existence of immigration-induced product demand shifts is also available for the UK, where Frattini (2009) finds that immigrant inflows between 1995 and 2006 increased the prices of low-value and everyday grocery goods-a result interpreted as stemming from demand side effects and which parallels some of our later findings for the retail sector.

Saiz (2007) and Cortes (2008) also study the effects of immigration on prices, but with a different focus. Saiz studies immigrants' demand for housing and subsequent changes in housing rents, while Cortes studies how immigration changes the price of domestically produced products through declines in labor costs.

As this brief review indicates, empirical research on how immigration affects host countries has recently moved away from its almost exclusive focus on labor markets to include effects on product demand and prices. Changes in prices are important because-aside from reflecting product demand shiftsthey affect real income and its distribution, in ways that depend on natives' consumption patterns. However, what are still largely ignored in most empirical research are the potential benefits from immigration in terms of increasing the variety of consumption choices in the destination country.

One of the commonly cited benefits of immigration is that the diversity of the population is enhanced. Although diversity is often touted as a benefit in and of itself, economic models can help explain why diversity might increase welfare. Lazear (2000), for example, builds a model in which the gains from diversity are greatest when groups have information sets that (1) are disjoint, (2) are relevant to one another, and (3) can be learned by the other group at low cost. He then empirically evaluates the argument in favor of immigrationinduced diversity using the 1990 Census and concludes that current immigration policy fails to foster diversity, while balanced immigration, promoted through the sale of immigration slots, would enrich the diversity of the US population. In other analyses of the economic effects of ethnic diversity (Ottaviano and Peri 2006, 2008; Sparber 2008; Amuedo-Dorantes and de la Rica 2008; Peri and Sparber 2009), the gains from diversity arise from productivity effects (e.g., because of the existence of complementarities between workers of different types).

In this paper, we define and study a different kind of diversity that may be induced by immigration - namely, we ask whether immigrant inflows increase the variety of products available for consumption. This diversity effect can arise for two reasons. First, immigrants consume and hence increase demand for "ethnic" goods. And second, they may have a comparative advantage in producing ethnic goods, hence increasing the supply of these goods ${ }^{2}$ (a similar

\footnotetext{
${ }^{2}$ See Chiswick (2009) for a formal treatment of the relevance of ethnicity for economic analysis through these two channels (that is, that ethnic groups differ in their consumption patterns as well as in their supply of resources).
} 
effect can stem from any kind of frictions or preferences that lead immigrants to increase labor supply in industries producing ethnic goods). The increased diversity of goods in the product market generated by immigration may then lead to welfare improvements for natives that have relatively stronger preferences for ethnic goods. ${ }^{3}$

In economics, there is a well-established trade literature modeling and estimating the welfare gains from increased varieties of traded goods. Broda and Weinstein (2006), building on the seminal work of Krugman (1979) and on the methodology developed by Feenstra (1994), model international trade within a framework of differentiated goods and estimate the contribution of imports of new varieties to national welfare in the USA. Using disaggregated US import data, they find that US consumers have low elasticities of substitution across similar goods produced in different countries, and calculate the gain from the threefold increase in import varieties between 1972 and 2001 to be $2.6 \%$ of GDP.

More closely related to what we do is the study by Ottaviano and Peri (2007), which adapts the concept of "consumption variety" effects to the study of the economic benefits of immigration. They develop a general equilibrium model for a small open economy where individuals are differentiated in terms of origin-home-born and foreign-born-and consume two goodsa homogenous tradable good and a differentiated local non-tradable good. Individuals of different origin are assumed to be able to produce different varieties of the non-tradable good. In this setting, the non-tradable good can be thought of as a composite basket of local services whose supply particularly benefits from "ethno-cultural" diversity, such as restaurants, retail trade, and entertainment. We build on the approach and attempt to directly study the relationship between immigrant inflows and the composition of products available to consumers, focusing on the retail sector and the restaurant sector. $^{4}$

\footnotetext{
${ }^{3}$ Waldfogel (2008) presents evidence consistent with the idea that an individual consumer's welfare can be affected by the agglomeration of individuals with particular tastes in the same market. He studies the relationship between the distribution of consumer types and the distribution of restaurants, and concludes that "agglomeration of demographically similar persons brings forth private products ... preferred by the agglomerating group" (p. 580). Although this research does not pertain to immigration per se, it makes the point that the entry of immigrants with similar tastes to a subgroup of natives may increase the provision of products preferred by those natives and hence increase their welfare, and more generally that the distribution of tastes in the market can affect the types of products offered. In the immigration literature, see Hatton and Leigh (2011) for a review of the interaction between ethnic groups and the host society, and the process by which the non-immigrant community accepts, accommodates, and adapts to inflows from particular immigrant groups.

${ }^{4}$ In the model of Ottaviano and Peri (2007), it is instead assumed that immigration increases the ethnic diversity of some local services. When calibrating the model to conditions in the USA, the authors specify restaurants and entertainment as the two sectors where immigration may induce ethnic diversity.
} 


\section{Empirical approach}

We use establishment-level data for California to study the relationships between changes in the composition of employment and businesses in a Census tract or other local area and immigrant inflows into the same and surrounding tracts. Before plunging directly into the analysis of the effects of immigration on variety, we present some preliminary analysis of the effects of immigration on employment in locally produced, non-traded industries, to establish that immigration into a local area affects such industries-a prerequisite for immigration to have effects on the variety of local output.

When immigrants flow into an area, they increase the demand for locally produced, non-traded goods (Altonji and Card 1991). In addition, the outward labor supply shift associated with immigration contributes to higher total employment in any industry in which labor supply increases, with the magnitude depending on how much the increase in labor supply lowers prices, how strongly native labor supply to the industry responds to potential wage declines, and the price elasticity of demand for products from which labor demand is ultimately derived (Borjas 2009). Of course, immigrant inflows may themselves be a response to outward demand shifts in industries that employ immigrants, so we have to be cautious about causal inferences.

These considerations have a few implications. First, to the extent that we want to detect demand effects of immigration, we should focus on nontradables. Second, although the labor supply effect of immigration can increase employment in any industry, it is only for non-tradables that we can reliably attribute a change in local variety to local immigration, so, again, we are more interested in this sector. And third, the effects might be different in industries that are intensive in the use of immigrants. In particular, to the extent that the supply effects of immigration are important, we ought to see more of an effect of immigration on employment in non-tradable industries that are immigrantintensive.

In addition to these considerations, given our focus on product variety we are most interested in industries in which we can infer something about variety based on employment patterns. We focus on the retail sector-which is non-traded and non-immigrant-intensive-and restaurants-which are also non-traded but are immigrant intensive. Much of our analysis in fact focuses on the restaurant industry, for which the link between establishments and consumption variety is most transparent; in particular, we study the ethnic variety of restaurants and how it is affected by immigration.

We look at the effects of immigration on product diversity along a number of dimensions. First, for retail stores, we examine how immigrant inflows are associated with changes in the numbers of chain versus stand-alone establishments, as well as establishments of different sizes. The idea behind this analysis is that a larger number of small and especially stand-alone establishmentsin contrast to large and/or chain stores-may be associated with increased diversity of consumption choices. Immigrant inflows might lead to a proliferation of small or stand-alone establishments to cater to the specific tastes 
of immigrants that might not be met by the larger, chain stores. On the other hand, if immigrants have greater price elasticities of demand (consistent with Lach 2007), or if they tend to consume the products in which the large chain stores specialize, their arrival could shift the composition of businesses in the opposite direction.

We then take this analysis in a narrower direction that more definitively identifies the effects of immigration on the diversity of consumption choices. Specifically, we examine whether immigrant inflows and increases in ethnic diversity in the local population are associated with a higher share of ethnic restaurants and greater diversity of the ethnicity of restaurants in the local market. Our analysis is based on detailed ethnic classifications of restaurants and characterizations of variety based on Herfindahl-Hirschman indexes. Although the focus on restaurants is narrow, the advantage of looking at this sector is that we know what types of goods a restaurant's consumers are purchasing. In contrast, even if we suggested above that growth of large chain stores at the expense of small retailers implies less diversity in consumption, chain stores, in principle, could offer a variety of ethnic goods-although casual observation suggests that their offerings are in fact quite homogenous.

Finally, we are generally not concerned with separating the effects of labor supply and labor demand shifts that immigration induces. Demand shifts can increase product diversity by changing the agglomeration of tastes in a market, and supply shifts may play a role in increasing the diversity of consumption choices under the likely assumption that immigrants have a comparative advantage at producing "ethnic" goods or because of price effects of increased labor supply to particular industries. However, some of our analysis attempts to assess whether the increased variety of ethnic restaurants that we find likely stems more from the demand or from the supply side.

\section{Data}

\subsection{Employment and business establishment composition}

Our dependent variables are constructed using data from the NETS database. The NETS is a longitudinal file created by Walls and Associates using Dun and Bradstreet $(\mathrm{D} \& \mathrm{~B})$ data, which covers all business establishments in the USA between 1989 and 2004. The unit of observation in the NETS is a business establishment, which is a business or industrial unit at a single physical location that produces or distributes goods or provides services. Using the headquarters' DUNS number, we can tell whether an establishment is a standalone firm or a branch of a multi-establishment firm. The data in the NETS do not come from a single survey. Rather, D\&B collects the underlying data through a massive data collection effort covering many sources, including over 100 million telephone calls to businesses each year, as well as obtaining information from legal and court filings, newspapers and electronic news services, public utilities, all US secretaries of state, government registries and 
licensing data, payment and collections information, company filings and news reports, and the US Postal Service. ${ }^{5}$

The NETS database does not contain detailed information about establishments, but it does include the business name, a unique D\&B establishment identifier (the DUNS number), the establishment location, detailed SIC industrial codes in each year (and a cross-walk to NAICS codes), the identifier of the firm's headquarters (also a DUNS number), and employment (as well as sales, which we do not use because it is usually imputed) in each year.

The NETS has unique advantages for the purposes of this study. First, after geocoding business establishments' addresses, we can map employment at the detailed geographic level; in our case, we do this at the level of the Census tract. ${ }^{6}$ Second, the NETS is designed to capture the universe rather than a sample of establishments, and hence covers essentially all firms and establishments. Third, unlike other sources of data on individual business establishments available through the Census Bureau or the Bureau of Labor Statistics, the NETS data are not confidential. We are, therefore, able to identify specific businesses both in our own work with the data and in the reporting of results. Both of these uses of specific business names are important in the ensuing analysis; we use company names to identify certain big-box retailers and to refine the ethnic classification of restaurants. On the other hand, a limitation of the NETS is that it includes no information on the composition of employment with respect to skill, immigrant status, or any other dimension.

We use an extract of the NETS data that covers all business establishments that were ever located in California between 1992 and 2002. ${ }^{7}$ Given that the Census of Population data that we use to measure immigrant inflows (discussed next) span a 10-year window ending in 2000, using 2002 as the ending year for our analysis makes sense. Moreover, evidence that the NETS sometimes detects business births with a lag (Neumark et al. 2007) implies that using a 10-year window that is shifted forward by a couple of years

\footnotetext{
${ }^{5}$ The NETS data construction effort-including both the cross-sectional files and the longitudinal linking that tracks establishments over time-is a massive and complicated one. Details are provided in Neumark et al. (2007). For more information about the NETS and comparisons to other data sources, see http://www.youreconomy.org/nets/NETSDatabaseDescription.pdf (viewed December 17, 2008). Although the data extend back to 1989, the data prior to 1992 are less reliable because only beginning in 1992 was D\&B able to purchase Yellow Page information on business units. We therefore use data beginning in 1992.

${ }^{6}$ The establishment locations were mapped to Census tracts with GIS software using the Census 2000 TIGER/Line files as our data source (downloaded from www.esri.com/data). The NETS contains the street address of each business establishment, but GIS mapping requires that these addresses be "geocoded" to latitude-longitude coordinates. We used a geocoded version of the NETS data that was constructed for another research project (Neumark and Kolko 2010).

${ }^{7}$ We only had access to the geocoded NETS data for California for this research. The results might not generalize to other states, especially those in which immigrant inflows are much smaller relative to the population.
} 
relative to the Census should provide more accurate measurement of changes in employment and the number and types of businesses associated with immigrant inflows. Census-tract level summary statistics of the variables used in the analysis are reported in Electronic Supplementary Material.

\subsection{Total and foreign-born population}

Data on total and foreign-born population by Census tract are from the 1990 and 2000 Censuses of Population. One question is how to define the size of the market in which to measure the immigrant inflows that may influence the diversity of consumption choices or reflect the availability of choices to consumers. We can identify immigrant inflows at the Census tract level. Two extreme choices would be to consider the data at the Census tract level or instead to aggregate up to the metropolitan statistical area (MSA). ${ }^{8}$ However, neither Census tracts nor MSAs seem to provide the right level of aggregation to identify the potential pool of customers or establishments located in a given tract: the former tend to be too small and also vary widely in size; the latter may be too large. And both are based on arbitrary boundaries that are likely to be crossed on a daily basis by residents, especially for Census tracts in densely populated areas and along borders shared by MSAs.

To circumvent these problems, we define the pool of potential customers for an establishment located in tract $c$ in year $t$ as the weighted sum of the population in tracts $k\left(k=1, \ldots, K_{c}\right)$ located in area $a(c)$-an area that encompasses but is larger than $c$, and is not arbitrarily restricted to MSA boundaries:

$$
\operatorname{Pop}_{a(c) t}=\sum_{k \in a(c)}\left\{w_{c k} \cdot \operatorname{Pop}_{k t}\right\},
$$

\footnotetext{
${ }^{8}$ Census tracts are designed to be relatively homogenous with respect to population characteristics, economic status, and living conditions. The spatial size of Census tracts varies widely depending on population density. In California there are 7,049 Census tracts, with an average population of 4,200 in 1990 and 4,800 in 2000. MSAs include counties that center on an urban core and are characterized by a high degree of social and economic integration (as measured by commuting to work) with the core. There are 25 MSAs in California, ranging from highly densely populated metro areas such as Los Angeles-Long Beach (including 2,054 tracts) to more sparsely populated areas such as Merced (including 47 tracts). The analyses reported in this paper exclude the 242 tracts located outside any MSA, which lie along the sparsely populated northern and eastern borders of the State.

Because Census geography changes over time, we must normalize 1990 and 2000 Census tract geographic definitions. Our primary data source is the Neighborhood Change Database (NCDB), which provides total and foreign-born population counts from each Census year for each year2000 Census tract, mapping the earlier data onto the current boundaries. In the analyses of the restaurant sector we also need figures on foreign-born population from different countries, which are not available in the NCDB. In this case, we use data from the Census Summary Files (SF4), and employ Census Bureau reports of tract level allocation factors to map 1990 tract variables to 2000 geography. We would like to thank Justin Marion and Nathaniel Baum-Snow for sharing their computer code to implement this procedure.
} 
where the weights $w_{c k}$ are functions of the distance between the center of tract $c$ and the center of tract $k$, which we denote $d_{c, k}{ }^{9}$

Assuming that the likelihood that consumers shop in tract $c$ decreases with the distance between $c$ and the tract where they live, we could arbitrarily specify $w_{c k}$ as some decreasing function of $d_{c, k}$. Instead, we define weights based on the distances consumers travel. In particular, using data from the 2001 National Household Travel Survey, we calculate summary statistics on the number of miles that Californians travel to go shopping. Figure 1 shows smoothed distributions of shopping trips by miles traveled, separately for residents in the MSAs of Los Angeles, Orange County, and Riverside (Panel A) and for residents in the remainder of the urbanized areas of California (Panel B). ${ }^{10}$ We group trips shorter than 5 miles into 1-mile-length bins, trips between 5 and 30 miles into 5-mile-length bins, and trips between 30 and 50 miles into one residual bin. We let $\delta$ index these 11 distance bins and denote by $p_{\delta}$ the proportions of shopping trips in each bin. These proportions are graphed in Fig. 1 (piecewise line). For each tract $c$, we then calculate the number of tracts that are $\delta$ miles away from $c\left(T_{c \delta}\right)$ and set the weights in Eq. 1 equal to:

$$
w_{c k}=\left\{\begin{array}{c}
\frac{p_{\delta}}{T_{c \delta}} \text { if } d_{c, k} \in \delta \\
0 \text { if } d_{c, k}>50
\end{array}\right.
$$

where the values of $p_{\delta}$ vary depending on whether tract $c$ is in the Los Angeles, Orange County-Riverside area, or elsewhere in the state. ${ }^{11}$

When characterizing consumption choices available to consumers, we apply the same weights to counts of establishments by type. Finally, since we have argued that the composition/variety effects of immigration may arise not only from immigrants' consumption choices but also from their labor supply; in some of our analyses of these latter effects, we also define weights that map the distribution of miles traveled by Californians to commute to work. In practice, these weights are constructed as in Eq. 2, where the $p_{\delta}$ 's represent

\footnotetext{
${ }^{9}$ In practice, the center of a tract is defined by its geometric center, or "centroid." Spherical coordinates of Census 2000 tract centroids were downloaded from the US Census Bureau (http://www. census.gov/geo/www/gazetteer/places2k.html) and converted to planar coordinates using ArcGIS software.

${ }^{10} \mathrm{We}$ do not disaggregate further because the sample is small.

${ }^{11}$ The idea behind dividing by $T_{c \delta}$ is the following. Suppose that tract $c$ is distance $d$ from tract $k$, and the travel data imply that the proportion $p$ of the trips of those residing in tract $k$ cover distance $d$. Residents of tract $k$ can travel in multiple directions, and we would not expect all those traveling distance $d$ to travel to tract $c$. Instead, we count the number of tracts that are distance $d$ from tract $c$, which we denote $T$, and assume that $1 / T$ of those who travel distance $d$ will travel to tract $c$. In principle one could try to refine this by taking account of roads and other travel infrastructure. Furthermore, this is a simplification, because one would really want to do this calculation separately for each tract $k$ within distance $d$ of tract $c$, calculating the share of those from each tract $k$ around tract $c$ that would travel to tract $c$. The simplified calculation we use, however, will still capture the variation in potential inflow from a surrounding tract depending on whether tracts in the area are geographically small or geographically large.
} 
the proportions of work trips of different length (piecewise lines in Fig. 2). A comparison of Figs. 1 and 2 reveals that individuals tend to travel longer distances to go to work than to go shopping.

\section{Econometric analysis}

\subsection{Preliminary evidence on effects of immigration on local industries}

We begin with a brief preliminary analysis relating the growth in employment in establishments in industry groupings (indexed by $i$ ) located in a given Census tract to inflows of immigrant residents into the same and surrounding tracts. Following the literature on the effects of immigration (e.g., Card 2001; Card and DiNardo 2000; Ortega and Peri 2009), we denote by $\Delta I_{t} / \mathrm{Pop}_{t-1}$ the immigration rate, namely the change in the foreign-born population from $(t-1)$ to $t$ relative to the total population in $(t-1)$ and estimate regression models of the form:

$$
\Delta E_{i c t} / E_{i c t-1}=\alpha_{i}+\beta_{i}^{N}\left(\Delta N_{a(c) t} / \operatorname{Pop}_{a(c) t-1}\right)+\beta_{i}^{I}\left(\Delta I_{a(c) t} / \mathrm{Pop}_{a(c) t-1}\right)+u_{i c t},
$$

where $E_{i c t}$ is the employment in establishments located in Census tract $c$ in year $t$. The equation also controls for the change in the native population $\Delta N$, which is treated symmetrically to the immigration rate and scaled as well relative to the initial total population. All population measures are defined in area $a(c)$ around Census tract $c$ using the weighting described in the previous subsection. Because the model is estimated in differences, it eliminates time-invariant Census tract characteristics that may be correlated with both employment and population.

In Eq. 3, comparisons of the estimates of $\beta_{i}^{N}$ and $\beta_{i}^{I}$ tell us how inflows of immigrants into a local area affect employment in industry $i$, compared to inflows of natives. As discussed earlier, we expect the inflow of immigrants (or natives) into an area to have more impact on product and hence labor demand in non-tradable industries. Moreover, to the extent that immigrants tend to work in particular (non-tradable) industries, those industries ought to experience larger employment increases stemming from the labor supply increase and hence the lowering of prices for that industry's output; therefore, we report results for non-tradable industries divided into those that are less and more immigrant-intensive. Finally, because our analysis of the effects of immigration on product diversity focuses on the retail sector and on restaurants, we also present preliminary evidence based on Eq. 3 for the retail sector and the accommodation and food services sector (which includes restaurants).

For the first classification, we would ideally categorize industries on the basis of estimates of the fraction of output that is non-traded. Since these estimates are not easily obtained, we have to rely on a standard, but somewhat arbitrary, classification of industries. Services have traditionally been classified 
$\mathbf{a}$

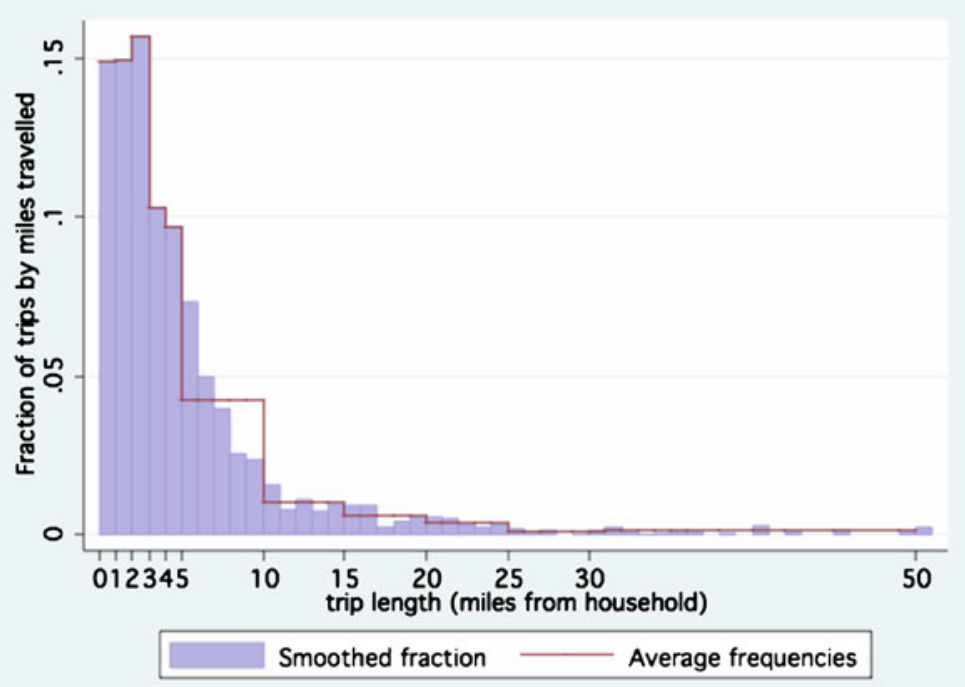

b

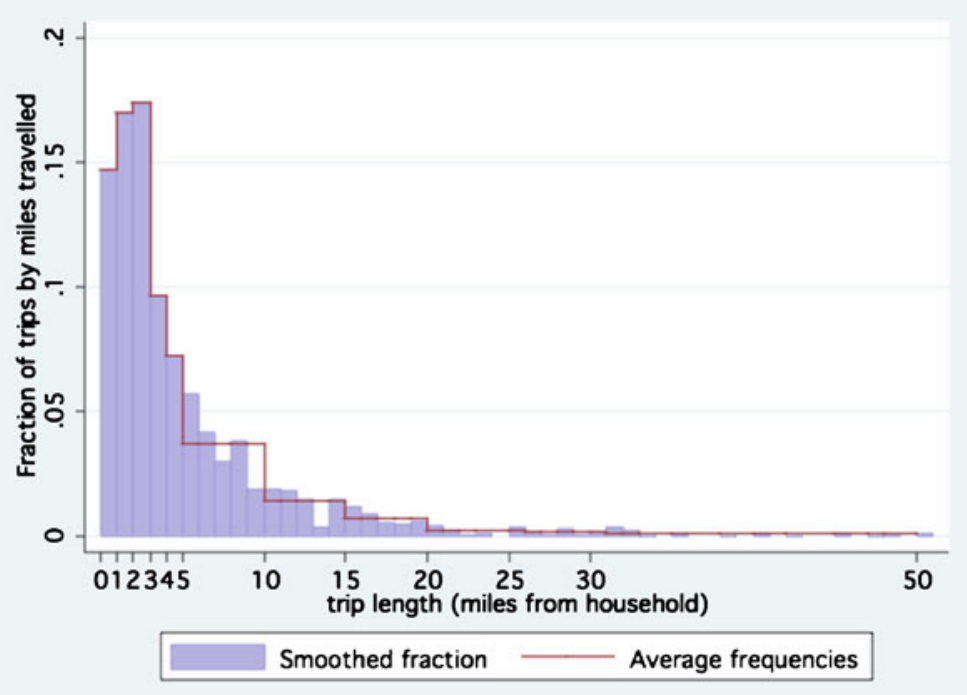

Fig. 1 Distribution of shopping trips by miles in California, 2001. a Los Angeles, Orange County, and Riverside MSAs. b Rest of California. The figures plot smoothed distributions of shopping trips by distance traveled (miles). The distance is between the person's residence and the shopping destination. The piecewise lines plot the average frequencies in 1-, 5- or 20-mile distance bins. Sample: (a) is based on 1,328 trips made for shopping purposes (general retail, food purchase, and personal services) by residents in Los Angeles, Orange County and Riverside; (b) is based on 1,628 shopping trips made by residents of urbanized areas in the rest of California. 2001 National Household Travel Survey 
a

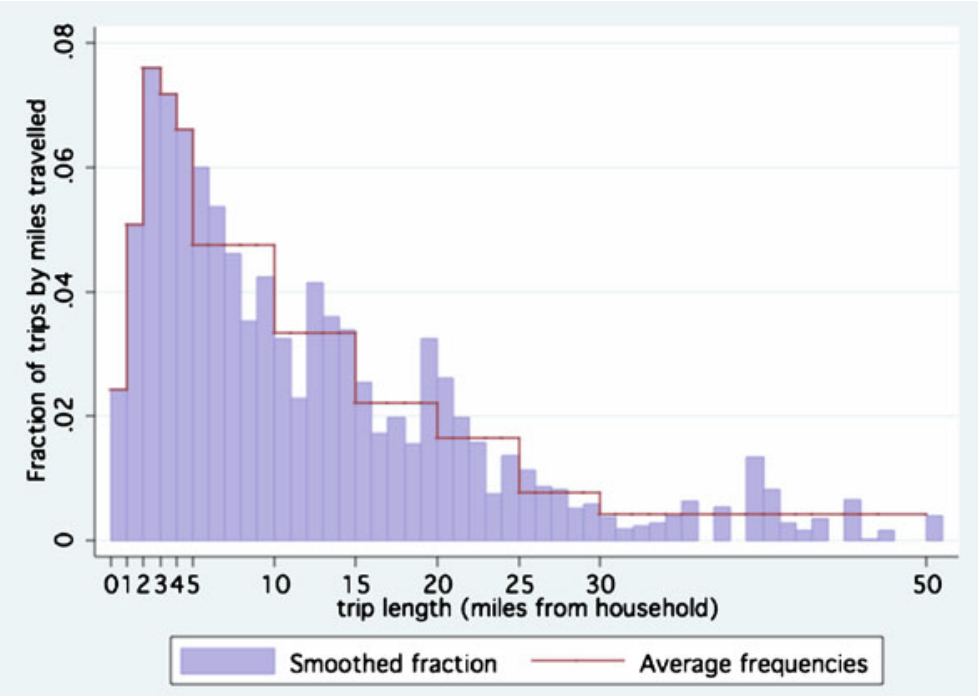

b

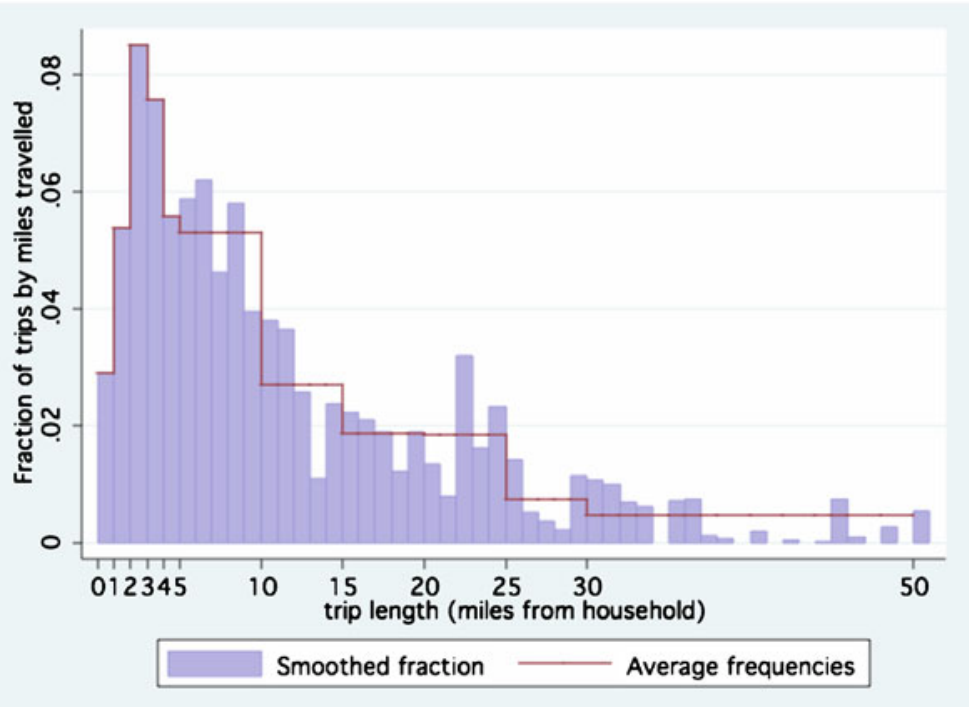

Fig. 2 Distribution of commuting-to-work trips by miles in California, 2001. a Los Angeles, Orange County, and Riverside MSAs. b Rest of California. The figures plot smoothed distributions of trips to work by distance traveled (miles). The distance is between the person's residence and the place of work. The piecewise lines plot the average frequencies in 1-, 5- or 20-mile distance bins. Sample: (a) is based on 598 trips made to go to work by residents in Los Angeles, Orange County, and Riverside; (b) is based on 695 trips made to go to work by residents of urbanized areas in the rest of California. 2001 National Household Travel Survey 
as non-tradable industries. More broadly, this is arguably an appropriate definition for retail trade, construction, educational services, health care, social assistance, food services, repair and maintenance, personal and laundry services, and private household services-and in what follows, we will refer to this set of industries as non-tradable. Industries including transportation, warehousing, accommodation services, and public administration, as well as information, and finance, insurance, and professional services, may more often serve a larger population than local residents (Jensen and Kletzer 2010), while agriculture, mining, manufacturing, utilities, and wholesale trade are more clearly classified as strictly traded sectors.

With regard to immigrant intensiveness, we use information on the existing differences in the likelihood of employment of foreign-born individuals across industries. ${ }^{12}$ As shown in Table 1, in 2000, foreign-born individuals made up around $31 \%$ of the total labor force in California. However, foreign-born shares in the labor force of (NAICS) two-digit industries were as high as $65 \%$ in agriculture and as low as $12 \%$ in mining-both industries that we classify as strictly tradable. Most of the other strictly tradable industries-that is, the manufacturing sub-industries and wholesale trade-have higher-than-average intensity in the use of immigrant labor. On the contrary, among non-tradable industries, some are more immigrant-intensive and others are less so. Note in particular that retail is below average in immigrant intensiveness, although still fairly intensive in the use of immigrants, while accommodation and food services is among the most immigrant-intensive industries. We might, then, expect the supply of immigrants to this sector-and restaurants in particularto play more of a role in the effects of immigration. ${ }^{13}$

Table 2 reports the estimates of Eq. 3 for different industry groups. Given the uneven distribution of employment by industry and tract, regressions are weighted by the number of employees in tract $c$ and industry $i$ in 1992. Standard errors are clustered at the MSA level to correct for heteroscedasticity and arbitrary correlation across tracts located in the same MSA. ${ }^{14}$

As shown in column 1, Panel A, a 1\% increase in native population is associated on average with a statistically significant $1.4 \%$ increase in employment when looking at all industries, whereas a similar increase in the immigrant population is associated with a smaller (but still significant) employment increase of $0.95 \%$; the difference between the effects of native versus immigrant population inflows is marginally significant $(p=0.11)$. When

\footnotetext{
${ }^{12}$ Of course, we cannot classify industries strictly on the basis of the immigrant-intensiveness of their labor input, in part because there is a continuum of characteristics, and in part because these characteristics are not immutable. For example, an industry that is non-intensive in immigrant labor can still absorb immigrant labor, and the composition of the labor input in different industries can change with immigration.

${ }^{13}$ Immigrant intensiveness in the restaurant sector (43.4\%) is virtually the same as in the broader accommodation and food services sector (43.5\%).

${ }^{14}$ The estimation results presented in the paper are robust to running unweighted regressions and to clustering the standard errors at a higher level (across the 17 Consolidated Metropolitan Statistical Areas in California).
} 
Table 1 Immigrant shares in the California labor force, by industry (2000)

\begin{tabular}{|c|c|c|c|c|}
\hline & & \multirow{2}{*}{$\begin{array}{l}\text { Immigrant } \\
\text { share }(\%)\end{array}$} & \multicolumn{2}{|c|}{ Percentage of labor force } \\
\hline & & & Total & Foreign-born \\
\hline Overall average & & 30.53 & & \\
\hline \multicolumn{5}{|l|}{ Industry } \\
\hline \multicolumn{5}{|l|}{ Above average } \\
\hline Agriculture, forestry, fishing, and hunting & TR & 65.16 & 1.97 & 4.04 \\
\hline Manufacturing: food and textile & TR & 61.75 & 2.27 & 4.63 \\
\hline Accommodation and food services & NT & 43.53 & 6.06 & 8.61 \\
\hline $\begin{array}{l}\text { Manufacturing: metal, electrical, } \\
\text { and electronic }\end{array}$ & TR & 43.08 & 8.49 & 12.07 \\
\hline Admin., support, waste mgmt. services & NT & 40.05 & 4.12 & 5.44 \\
\hline Repair, personal, household services & NT & 39.54 & 5.04 & 6.56 \\
\hline Manufacturing: paper and chemical & TR & 38.03 & 2.42 & 3.03 \\
\hline Wholesale trade & TR & 36.75 & 4.02 & 4.88 \\
\hline Construction & NT & 31.41 & 6.24 & 6.37 \\
\hline \multicolumn{5}{|l|}{ Below average } \\
\hline Mail and warehousing & - & 28.98 & 1.28 & 1.23 \\
\hline Transportation & - & 28.43 & 2.68 & 2.50 \\
\hline Retail trade: miscellaneous & NT & 28.27 & 7.12 & 6.63 \\
\hline Health care and social assistance & NT & 28.10 & 9.88 & 9.11 \\
\hline Retail trade: hobby and general & NT & 24.86 & 3.89 & 3.17 \\
\hline Real estate, rental, and leasing & - & 23.24 & 2.13 & 1.63 \\
\hline Finance and insurance & - & 22.93 & 4.63 & 3.48 \\
\hline Professional, scientific, and technical serv. & - & 22.59 & 7.25 & 5.39 \\
\hline Management of companies/enterprises & - & 19.12 & 0.04 & 0.02 \\
\hline Information & - & 19.11 & 3.90 & 2.48 \\
\hline Arts, entertainment, and recreation & - & 18.73 & 2.06 & 1.25 \\
\hline Educational services & NT & 17.24 & 8.41 & 4.74 \\
\hline Utilities & TR & 14.70 & 0.77 & 0.38 \\
\hline Public administration & - & 13.41 & 5.16 & 2.28 \\
\hline Mining & TR & 12.23 & 0.16 & 0.06 \\
\hline
\end{tabular}

NAICS two-digit industries ranked by the share of foreign-born in the labor force, from the most immigrant-intensive sector to the least

2000 Census

$T R$ traded industries; $N T$ non-traded industries

we restrict attention to non-tradable industries, in column (2), we see-as expected-larger effects of both types of population inflows. Again, the effect of immigrants is smaller than the effect of natives, although the difference is not significant. Nonetheless, the lower point estimates for immigrant inflows may reflect the fact that immigrants are on average lower earners, and remit some of their income to their home countries. ${ }^{15}$

Columns (3) and (4) break up non-tradable industries into non-immigrantintensive and immigrant-intensive. Contrary to what we might expect if immigrants tend to push out labor supply in immigrant-intensive industries (and

\footnotetext{
${ }^{15}$ Immigrants are also younger. In 2000 Census data for California, the share of prime-age individuals (25-44 years old) was $49 \%$ among the adult foreign-born population, but only $37 \%$ among natives. On the contrary, the shares over 65 were, respectively, $10 \%$ and $17 \%$.
} 
Table 2 Percentage growth in employment across Census tracts and immigrant and native population growth in surrounding areas

\begin{tabular}{|c|c|c|c|c|c|c|}
\hline & $\begin{array}{l}\text { All } \\
\text { industries } \\
\text { (1) }\end{array}$ & $\begin{array}{l}\text { Non- } \\
\text { traded } \\
\text { (2) }\end{array}$ & $\begin{array}{l}\text { Non-traded, } \\
\text { non-immigrant } \\
\text { intensive } \\
\text { (3) }\end{array}$ & $\begin{array}{l}\text { Non-traded, } \\
\text { immigrant } \\
\text { intensive } \\
\text { (4) }\end{array}$ & $\begin{array}{l}\text { Retail } \\
\text { (5) }\end{array}$ & $\begin{array}{l}\text { Accommodation } \\
\text { and food } \\
\text { (6) }\end{array}$ \\
\hline $\begin{array}{l}\text { Percentage } \\
\text { growth in } \\
\text { native } \\
\text { population }\end{array}$ & $\begin{array}{l}1.385^{\mathrm{a}} \\
(0.132)\end{array}$ & $\begin{array}{l}1.893^{\mathrm{b}} \\
(0.210)\end{array}$ & $\begin{array}{r}2.654^{\mathrm{a}} \\
(0.310)\end{array}$ & $\begin{array}{r}1.824^{\mathrm{a}} \\
(0.510)\end{array}$ & $\begin{array}{r}2.997^{\mathrm{a}} \\
(0.581)\end{array}$ & $\begin{array}{r}5.281^{\mathrm{a}} \\
(0.917)\end{array}$ \\
\hline $\begin{array}{l}\text { Percentage } \\
\text { growth in } \\
\text { immigrant } \\
\text { population }\end{array}$ & $\begin{array}{r}0.945^{\mathrm{a}} \\
(0.232)\end{array}$ & $\begin{array}{r}1.321^{\mathrm{a}} \\
(0.432)\end{array}$ & $\begin{array}{r}1.119^{\mathrm{b}} \\
(0.451)\end{array}$ & $\begin{array}{c}0.690 \\
(1.417)\end{array}$ & $\begin{array}{r}1.078^{\mathrm{b}} \\
(0.437)\end{array}$ & $\begin{array}{r}4.250^{\mathrm{b}} \\
(1.968)\end{array}$ \\
\hline Constant & $\begin{array}{l}0.036 \\
(0.027)\end{array}$ & $\begin{array}{r}0.085^{\mathrm{c}} \\
(0.050)\end{array}$ & $\begin{array}{r}0.250^{\mathrm{a}} \\
(0.039)\end{array}$ & $\begin{array}{c}0.287 \\
(0.207)\end{array}$ & $\begin{array}{l}0.257^{\mathrm{a}} \\
(0.078)\end{array}$ & $\begin{array}{r}0.421^{\mathrm{b}} \\
(0.158)\end{array}$ \\
\hline Observations & 6,793 & 6,789 & 6,776 & 6,782 & 6,753 & 5,960 \\
\hline $\begin{array}{l}\text { F-test } \\
\qquad\left(\mathrm{H}_{0}: \beta^{N}=\beta^{I}\right)\end{array}$ & 2.711 & 1.455 & 6.528 & 0.836 & 9.982 & 0.245 \\
\hline Probability $>F$ & 0.113 & 0.240 & 0.017 & 0.370 & 0.004 & 0.625 \\
\hline
\end{tabular}

Dependent variable: 1992-2002 percentage change in the number of employees in establishments located in a Census tract in the industry or industries indicated. Immigrant and native population figures are defined as the weighted sum of the population in surrounding tracts in the 1990 and 2000 Censuses, with weights reflecting the distribution of shopping trips from the National Household Travel Survey, 2001. The number of observations varies across columns because Census tracts with no observations in an industry in 1992 are dropped. The universe is 6,793 populated Census tracts located within one of the 25 MSAs in California. Estimates are weighted by the tract-industry employment level in 1992. Standard errors (in parentheses) are clustered at the MSA level

${ }^{\text {a }}$ Significant at $1 \%$ level

${ }^{\mathrm{b}}$ Significant at $5 \%$ level

${ }^{\mathrm{c}}$ Significant at $10 \%$ level

NETS; Neighborhood Change Database, 1990 and 2000 Censuses

this may not be what happens because of, for example, natives' employment responses), the estimated effect of immigration on employment in the immigrant-intensive industries is smaller ( 0.69 versus 1.12$)$, and is imprecisely estimated.

To focus more sharply on the sectors on which we concentrate in our main analysis of immigration and product diversity, columns (5) and (6) report results for the retail and the accommodation and food services industries. The results for retail are similar to those for non-traded industries overall and even more so to non-traded, non-immigrant-intensive industries (column (3)). In particular, the effect of immigrant inflows is substantially weaker than that of native inflows. In contrast, for accommodation and food services, the effects of both native and immigrant inflows are large, and the effect of immigrants is almost as large as (and not significantly different from) the effect of native inflows.

This preliminary analysis leads to a couple of conclusions, as well as setting the stage for some of the analyses we report next. First, immigrant inflows are 
associated with increased employment in both retail and accommodation and food services. This provides some prima facie evidence for studying the effects of immigration on the composition of output in these industries. Second, the effect is much greater in the latter industry, which is at least consistent with labor supply mattering more in the accommodation and food services industry. This is consistent with other evidence we report below on how immigrants affect product diversity in the restaurant sector. At the same time, we do not find similar evidence of a larger relative (or absolute) effect of immigration on non-traded, immigrant-intensive industries generally, perhaps because, in this case, immigrants move into industries that have not been as immigrantintensive in the past. The pattern could be different in the restaurant sector because of a comparative advantage of immigrants in the production of ethnic food corresponding to their country of origin. Below, we present evidence consistent with this as well.

\subsection{Econometric analysis of the composition/diversity effects of immigration}

We now turn to evidence on the effects of immigration on the variety of consumption choices available to natives. We estimate models that relate changes in measures of the composition of businesses (such as the share of establishments of a certain type $K$, e.g., defined by size) to measures of changes in the composition of the population by nativity and ethnicity (such as the share of immigrants over the total population). Our interest in this analysis is in how immigration affects the consumption options of residents of a particular Census tract. Because these residents may travel to surrounding tracts when they shop or go out to eat, and because the consumption choices in these surrounding tracts (as well as their own tract) are likely, in general, to be shaped in part by the role of immigrants as consumers, in this analysis both the dependent and independent variables are defined as aggregates of tracts that correspond to the shopping area centered on a given tract of residence $c$, using the weights defined in Eq. 2. We therefore estimate equations of the form:

$$
\Delta \log \operatorname{Estab}^{\mathrm{type} K} \text { share }_{a(c) t}=\eta+\delta \Delta \log (I / \mathrm{Pop})_{a(c) t}+\phi \Delta \log \mathrm{Pop}_{a(c) t}+\xi_{a(c) t} .
$$

The dependent variable is the change in the log of the share of establishments that are of type $K$. The coefficient $\delta$ captures the potential effect of the immigrant share of the population on the composition of businesses. Since size per se arguably leads to more diversity, ${ }^{16}$ the equation also controls for changes in the population. Because the equation is estimated in first differences with an intercept, the estimates are not influenced by aggregate

\footnotetext{
${ }^{16}$ For example, in Krugman (1979), growth in the labor force (which may stem from immigration, as well as from other changes) increases varieties available in the market solely because of economies of scale in production.
} 
time-series relationships between structural changes in the economy-such as the advent of big-box retailing - and immigration.

When we turn to the narrower analysis of restaurants, the consumption choices available to natives may also be shaped by the role of immigrants as workers, because immigrants may have a comparative advantage in the production of ethnic goods. In this analysis, therefore, we also estimate equations where the immigrant share of the population is defined in area $a(c)$ centered on $c$, but defined using weights that map the distribution of commuting-to-work trips, rather than the distribution of shopping trips.

\subsection{Retail stores}

We focus first on the retail sector. Table 3 looks at changes in the share or number of stores by size of the business, using three size categories: stores with 1 to 9, 10 to 99, and 100 or more employees. As shown in Panel A, columns (1) through (3), growth in the share of the foreign-born population is associated with a decline in the share of very small retail establishments and increases in

Table 3 Growth of establishments of different sizes and growth in the foreign-born share across bundles of Census tracts

\begin{tabular}{|c|c|c|c|c|c|c|}
\hline \multirow{2}{*}{$\begin{array}{l}\text { Retail stores } \\
\text { Number of employees }\end{array}$} & \multicolumn{3}{|l|}{ All } & \multicolumn{3}{|c|}{$\begin{array}{l}\text { Food, clothing, general merchandise, } \\
\text { miscellaneous }\end{array}$} \\
\hline & $\begin{array}{l}1-9 \\
(1)\end{array}$ & $\begin{array}{l}10-99 \\
(2)\end{array}$ & $\begin{array}{l}100+ \\
(3)\end{array}$ & $\begin{array}{l}1-9 \\
(4)\end{array}$ & $\begin{array}{l}10-99 \\
(5)\end{array}$ & $\begin{array}{l}100+ \\
(6)\end{array}$ \\
\hline \multicolumn{7}{|c|}{ Panel A: Dependent variable: $\Delta$ log share of stores } \\
\hline$\Delta \log$ foreign share & $\begin{array}{r}-0.041^{\mathrm{b}} \\
(0.017)\end{array}$ & $\begin{array}{r}0.255^{\mathrm{c}} \\
(0.136)\end{array}$ & $\begin{array}{c}0.390 \\
(0.258)\end{array}$ & $\begin{array}{r}-0.048^{\mathrm{b}} \\
(0.018)\end{array}$ & $\begin{array}{r}0.357^{\mathrm{b}} \\
(0.156)\end{array}$ & $\begin{array}{c}0.280 \\
(0.280)\end{array}$ \\
\hline$\Delta \log$ population & $\begin{array}{r}-0.030^{\mathrm{c}} \\
(0.015)\end{array}$ & $\begin{array}{r}0.273^{b} \\
(0.127)\end{array}$ & $\begin{array}{c}0.280 \\
(0.214)\end{array}$ & $\begin{array}{r}-0.019 \\
(0.014)\end{array}$ & $\begin{array}{l}0.244 \\
(0.152)\end{array}$ & $\begin{array}{r}0.409^{\mathrm{c}} \\
(0.213)\end{array}$ \\
\hline \multicolumn{7}{|c|}{ Panel B: Dependent variable: $\Delta$ log number of stores } \\
\hline$\Delta$ log foreign share & $\begin{array}{r}-0.374^{b} \\
(0.141)\end{array}$ & $\begin{array}{r}-0.078^{\mathrm{c}} \\
(0.041)\end{array}$ & $\begin{array}{c}0.056 \\
(0.194)\end{array}$ & $\begin{array}{r}-0.386^{\mathrm{c}} \\
(0.209)\end{array}$ & $\begin{array}{c}0.019 \\
(0.108)\end{array}$ & $\begin{array}{c}-0.059 \\
(0.193)\end{array}$ \\
\hline$\Delta \log$ population & $\begin{array}{r}0.703^{\mathrm{a}} \\
(0.151)\end{array}$ & $\begin{array}{r}1.006^{\mathrm{a}} \\
(0.121)\end{array}$ & $\begin{array}{r}1.013^{\mathrm{a}} \\
(0.176)\end{array}$ & $\begin{array}{r}0.804^{\mathrm{a}} \\
(0.140)\end{array}$ & $\begin{array}{r}1.067^{\mathrm{a}} \\
(0.138)\end{array}$ & $\begin{array}{r}1.232^{\mathrm{a}} \\
(0.214)\end{array}$ \\
\hline
\end{tabular}

Dependent variable: Change in the log of the share (Panel A) or the log of the number (Panel B) of retail establishments with one to nine employees, 10 to 99 employees, or 100 or more employees. Sample in columns (1)-(3) is restricted to establishments with NAICS two-digit codes 44 and 45 (retail trade). Sample in columns (4)-(6) is restricted to establishments with NAICS 3-digit codes: 445 (grocery stores); 448 (clothing stores, except luggage and leather goods); 452 (department and other general merchandise stores); and 453 (miscellaneous stores, except pet supplies stores and manufactured home dealers). Both dependent variables and population figures are defined for aggregates of tracts, with weights reflecting the distribution of shopping trips from the National Household Travel Survey, 2001. Observations: 6,807 tracts within MSAs. Estimates are weighted by the number of retail establishments across aggregates of tracts in 1992. Standard errors (in parentheses) are clustered at the MSA level

a Significant at $1 \%$ level

b Significant at $5 \%$ level

${ }^{c}$ Significant at $10 \%$ level

NETS; Neighborhood Change Database, 1990 and 2000 Censuses 
the shares of both medium-sized and large stores (although the latter effect is not statistically significant). As shown in Panel B, this compositional change stems from a drop in the number of small stores. The estimates imply that a $10 \%$ increase in the share of the foreign-born population is associated with a $4 \%$ drop in the number of small establishments.

As suggested earlier, a decreasing share or number of small retail establishments may be associated with less diverse consumption choices. This argument is more likely to hold for products such as food, clothes, or other consumption goods such as decorations and gifts but is likely less relevant for items such as auto parts, hardware, or electronics-because the latter are more likely to be uniform across stores of different sizes, and at any rate unlikely to display variation in the "ethnicity" of goods. Therefore, we next restrict the analysis to the subset of the retail sector in which it is more likely that more small stores implies greater diversity (possibly along ethnic lines); we define this subset to include grocery, clothing and general merchandise stores, as well as a series of miscellaneous stores that specialize in items such as art supplies, posters, coins, decorations, or collectibles. As shown in columns (4) through (6), in this case, also, growth in the share of the foreign-born population is associated with a drop in both the number and share of very small retail stores, and growth in the share of larger stores.

In the next two tables, we look at the same question but characterizing the composition of retail stores differently. In Table 4, we study the differential growth in small businesses identified on the basis of the number of establishments in California with the same DUNS headquarter number. First, we identify stand-alone stores as those with no other establishments in California with the same DUNS headquarter number. We find that an increasing share of immigrants in the population is associated with both smaller shares of and fewer stand-alone stores (columns (1) and (4)). We find similar results when extending the analysis to a more broadly defined group of small businessesincluding not only stand-alone stores but also small chains, which are identified as stores for which no more than nine other stores share the same DUNS headquarter number (columns (2) and (5)). As it turns out, though, these findings are driven by the stand-alone stores; when we run the analysis separately for small chains but excluding the stand-alone stores (columns (3) and (6)), we find that an increasing share of immigrants in the population is associated with a larger share of stores in small chains (and no effect on the number of such stores). Thus, the sharpest result is that an increasing immigrant share is associated with declines in stand-alone retail stores.

In Table 5, we look instead at large chains. Specifically, we exploit the nonconfidentiality of the NETS data to examine effects of immigrant inflows on particularly large and well-known big-box retailers. Columns (1) and (2) use a narrow list, including Wal-Mart, Kmart, Costco, Target, Lowe's, and Sears, while in columns (3) and (4) the list is expanded to also include Best Buy, Home Depot, Staples, Office Depot, Circuit City, and Fry's. The first list captures general big-box retailers, and the second includes more-specialized ones. In 1992, there was on average one big-box retailer from the short list for 
Table 4 Growth of stand-alone or small-chain establishments and growth in the foreign-born share across bundles of Census tracts

\begin{tabular}{|c|c|c|c|c|c|c|}
\hline \multirow{2}{*}{$\begin{array}{l}\text { Retail sector } \\
\text { Number of stores with } \\
\text { same headquarter }\end{array}$} & \multicolumn{3}{|l|}{ All } & \multicolumn{3}{|c|}{$\begin{array}{l}\text { Food, clothing, general merchandise, } \\
\text { miscellaneous }\end{array}$} \\
\hline & $\begin{array}{l}\text { One } \\
(1)\end{array}$ & $\begin{array}{l}1-10 \\
(2)\end{array}$ & $\begin{array}{l}2-10 \\
(3)\end{array}$ & $\begin{array}{l}\text { One } \\
(4)\end{array}$ & $\begin{array}{l}1-10 \\
(5)\end{array}$ & $\begin{array}{l}2-10 \\
(6)\end{array}$ \\
\hline \multicolumn{7}{|c|}{ Panel A: Dependent variable: $\Delta$ log share of stand-alone or small-chain stores } \\
\hline$\Delta \log$ foreign share & $\begin{array}{r}-0.092^{\mathrm{a}} \\
(0.022)\end{array}$ & $\begin{array}{r}-0.066^{\mathrm{a}} \\
(0.014)\end{array}$ & $\begin{array}{r}0.296^{\mathrm{b}} \\
(0.124)\end{array}$ & $\begin{array}{r}-0.089^{\mathrm{a}} \\
(0.030)\end{array}$ & $\begin{array}{r}-0.066^{\mathrm{a}} \\
(0.021)\end{array}$ & $\begin{array}{l}0.335^{\mathrm{b}} \\
(0.158)\end{array}$ \\
\hline$\Delta \log$ population & $\begin{array}{r}-0.059^{b} \\
(0.024)\end{array}$ & $\begin{array}{r}-0.051^{\mathrm{a}} \\
(0.015)\end{array}$ & $\begin{array}{c}0.204 \\
(0.144)\end{array}$ & $\begin{array}{r}-0.039 \\
(0.026)\end{array}$ & $\begin{array}{r}-0.042^{\mathrm{a}} \\
(0.014)\end{array}$ & $\begin{array}{c}0.073 \\
(0.239)\end{array}$ \\
\hline \multicolumn{7}{|c|}{ Panel B: Dependent variable: $\Delta$ log number of stand-alone or small chain stores } \\
\hline$\Delta \log$ foreign share & $\begin{array}{r}-0.425^{\mathrm{a}} \\
(0.144)\end{array}$ & $\begin{array}{r}-0.399^{\mathrm{a}} \\
(0.137)\end{array}$ & $\begin{array}{r}-0.037 \\
(0.122)\end{array}$ & $\begin{array}{r}-0.427^{c} \\
(0.222)\end{array}$ & $\begin{array}{r}-0.403^{\mathrm{c}} \\
(0.212)\end{array}$ & $\begin{array}{c}-0.003 \\
(0.128)\end{array}$ \\
\hline$\Delta \log$ population & $\begin{array}{r}0.674^{\mathrm{a}} \\
(0.158)\end{array}$ & $\begin{array}{c}0.682^{\mathrm{a}} \\
(0.149)\end{array}$ & $\begin{array}{r}0.937^{\mathrm{a}} \\
(0.115)\end{array}$ & $\begin{array}{c}0.784^{\mathrm{a}} \\
(0.148)\end{array}$ & $\begin{array}{c}0.780^{\mathrm{a}} \\
(0.138)\end{array}$ & $\begin{array}{c}0.895^{a} \\
(0.210)\end{array}$ \\
\hline
\end{tabular}

Dependent variable: Change in the log of the number of establishments with unique headquarter DUNS number in California (columns (1) and (4)), or whose headquarter DUNS number is shared by no more than nine other establishments in California, either including stand-alone stores (columns (2) and (5)) or excluding them (columns (3) and (6)). Both dependent variables and population figures are defined for aggregates of tracts, with weights reflecting the distribution of shopping trips from the National Household Travel Survey, 2001. Observations: 6,807 tracts within MSAs. Estimates are weighted by the number of retail establishments across aggregates of tracts in 1992. Standard errors (in parentheses) are clustered at the MSA level

a Significant at $1 \%$ level

b Significant at $5 \%$ level

c Significant at $10 \%$ level

NETS; Neighborhood Change Database, 1990 and 2000 Censuses

every 13 Census tracts, and one big-box retailer from the long list for every nine tracts. For the two definitions, the average change in the number of bigbox stores between 1992 and 2002 is one more store for every 23 tracts (short list) or nine tracts (long list). Most of the establishments that belong to these chains are reported to belong to the retail sector, but there are some cases in which the sector of activity is wholesale trade (on average, fewer than $10 \%$ ). In columns (1) and (3), we consider all establishments belonging to each chain, and in columns (2) and (4), we restrict attention to the retail stores only, as in the preceding analyses in this section.

For these different definitions, we regress the change in the number of big-box retail establishments on the change in the share of the foreign-born population and the change in the log total population. ${ }^{17}$ The estimates indicate that increases in the immigrant share are associated with more big-box retail establishments. In particular, the estimates in columns (2) and (4) imply that a 10-percentage point increase in the foreign-born population (which is the standard deviation of the foreign-born share across tracts) is associated with

\footnotetext{
${ }^{17}$ Note that in this case, because of the large number of tracts with no big-box outlets, the dependent variable is the change in levels rather than the change in logs.
} 
Table 5 Changes in the number of big-box retailers and changes in the foreign-born share across bundles of Census tracts

\begin{tabular}{|c|c|c|c|c|}
\hline \multirow{2}{*}{$\begin{array}{l}\text { Big-box retailers } \\
\text { Reported sector } \\
\text { of activity }\end{array}$} & \multicolumn{2}{|l|}{ Short list } & \multicolumn{2}{|l|}{ Long list } \\
\hline & $\begin{array}{l}\text { Wholesale and } \\
\text { retail trade } \\
\text { (1) }\end{array}$ & $\begin{array}{l}\text { Retail trade } \\
\text { only } \\
\text { (2) }\end{array}$ & $\begin{array}{l}\text { Wholesale and } \\
\text { retail trade } \\
\text { (3) }\end{array}$ & $\begin{array}{l}\text { Retail trade } \\
\text { only } \\
\text { (4) }\end{array}$ \\
\hline \multicolumn{5}{|c|}{ Panel A: Dependent variable: $\Delta$ number of big-box retailer establishments } \\
\hline$\Delta$ foreign share & $\begin{array}{r}0.129^{\mathrm{b}} \\
(0.062)\end{array}$ & $\begin{array}{r}0.168^{\mathrm{b}} \\
(0.069)\end{array}$ & $\begin{array}{c}0.222 \\
(0.150)\end{array}$ & $\begin{array}{r}0.247^{\mathrm{c}} \\
(0.135)\end{array}$ \\
\hline$\Delta \log$ population & $\begin{array}{r}0.093^{\mathrm{a}} \\
(0.017)\end{array}$ & $\begin{array}{r}0.085^{\mathrm{a}} \\
(0.018)\end{array}$ & $\begin{array}{r}0.131^{\mathrm{a}} \\
(0.028)\end{array}$ & $\begin{array}{r}0.126^{\mathrm{a}} \\
(0.027)\end{array}$ \\
\hline \multicolumn{5}{|c|}{ Panel B: Dependent variable: $\Delta$ big-box retail/total retail establishments } \\
\hline$\Delta$ foreign share & & $\begin{array}{l}0.008 \\
(0.006)\end{array}$ & & $\begin{array}{c}0.019^{\mathrm{c}} \\
(0.009)\end{array}$ \\
\hline$\Delta \log$ population & & $\begin{array}{r}0.008^{a} \\
(0.002)\end{array}$ & & $\begin{array}{r}0.010^{\mathrm{a}} \\
(0.002)\end{array}$ \\
\hline
\end{tabular}

Dependent variable: Change in the number or share of big-box retailers: Wal-Mart, Kmart, Costco, Target, Lowe's, and Sears (columns (1) and (2)); these as well as Best Buy, Home Depot, Staples, Office Depot, Circuit City, and Fry's (columns (3) and (4)). Both dependent variables and population figures are defined for aggregates of tracts, with weights reflecting the distribution of shopping trips from the National Household Travel Survey, 2001. Observations: 6,807 tracts within MSAs. Standard errors (in parentheses) are clustered at the MSA level

a Significant at $1 \%$ level

${ }^{b}$ Significant at $5 \%$ level

c Significant at $10 \%$ level

NETS; Neighborhood Change Database, 1990 and 2000 Censuses

one more big-box store from the short list for every 59 tracts, and one more bigbox store from the long list for every 40 tracts. As shown in Panel B, increases in the share foreign-born are also associated with increases in the number of big-box retailers as a fraction of all retail establishments, although the estimate is significant only for the longer list of big-box chains.

A potential issue in interpreting the estimates of the coefficients on the change in the foreign-born share of the population in this last analysis is the endogenous location of immigrants. Despite using first differences, we cannot rule out bias from time-varying local factors associated with changes in both the number or type of retail establishments and immigrant inflows. Big-box retailers may locate in areas where land values are increasing more slowly than in other areas, a factor that may also be associated with larger immigrant inflows. We cannot directly test this hypothesis, but we did find that between 1990 and 2000 the foreign-born population share did not grow faster in areas with a larger concentration of big-box retailers in 1992, providing some evidence against this particular non-causal interpretation of our estimates. ${ }^{18}$ Moreover, recent evidence (Saiz 2003, 2007; Ottaviano and Peri 2007) suggests

\footnotetext{
${ }^{18}$ We study the association (across tracts and aggregates of tracts) between the 1990-2000 changes in the share of the foreign-born population and the share of big-box retailers (in the total number of stores) in 1992. The association is negative across tracts, and positive, but not statistically significant, across aggregates of tracts based on the weights we use in the regression analysis.
} 
that immigrant inflows increase rather than decrease rents. This combined evidence appears to rule out the possibility that immigrants either flowed into areas of declining land values (which therefore would have already had more big-box retailers), or caused land values to decline, which could have led to a greater concentration of such retailers.

If we assume that diversified products are more likely to be provided by a large number of stand-alone retail stores, and less likely to be provided by chain stores and especially big-box retailers, then the findings reported in this section suggest that, rather than increasing diversity, immigrants may have the opposite effect. This could be due to lower income levels, greater thrift, or greater price sensitivity that favors Wal-Marts over smaller outlets. ${ }^{19}$ However, an important caveat is that we have no information on the types of goods that consumers can buy at different stores. For example, one might associate a bigbox retail store with more uniformity of consumption choices than an equal volume of goods sold by numerous small stand-alone stores. But that may not always be true. It is possible that we need, for example, a Mexican, Indian, and Ethiopian grocery store in a local market in order to be able to buy tortillas, $n a$ 'an, and injera, in addition to the white and whole wheat bread at the local Safeway or IGA. But it is also possible that large big-box retailers have the capacity to supply a greater variety of types of bread, including many ethnic choices. Moreover, many stand-alones are not necessarily purveyors of ethnic goods. For example, casual observation suggests that many of the bodegas in Manhattan carry similar inventories of food items. Because of this inherent limitation in being able to draw conclusions based simply on the number, size, and composition of retail outlets, in the next section we turn to the analysis of the restaurant sector, for which we can much more readily associate the type and variety of establishments with the nature of the consumption choices they offer.

\subsection{Ethnic restaurants}

The industrial classification of establishments in the NETS is extraordinarily rich: the dataset includes an 8-digit SIC code that in the case of eating places separately identifies restaurants of 15 different ethnicities. The full list of ethnic categories as well as other types of eating places is provided in Table 6. On the other hand, a shortcoming of the NETS data is that around $40 \%$ of establishments in the restaurant sector are generally classified as "eating places," without identification of a specific category. The availability of the company name, however, allows us to substantially refine the classification. For example, we can easily identify establishments that belong to well-known chains such as MacDonald's or Taco Bell (examples of fast-food places),

\footnotetext{
${ }^{19} \mathrm{We}$ are interested in the effects of immigrant inflows without conditioning on their income, as the relevant question is the effect of the immigrant inflows actually experienced by the areas we study, not what would have happened if there were inflows of immigrants with incomes the same as natives.
} 
Table 6 Distribution of eating places in California by 8-digit SIC categories, 1992 and 2002

\begin{tabular}{|c|c|c|c|c|}
\hline \multirow[t]{2}{*}{ SIC 8-digit industry } & \multicolumn{2}{|c|}{ Reported \% } & \multicolumn{2}{|c|}{ Recoded \% } \\
\hline & 1992 & 2002 & 1992 & 2002 \\
\hline Eating places & 42.26 & 39.37 & 24.30 & 20.16 \\
\hline Ethnic food restaurants & 0.83 & 1.06 & 0.37 & 0.49 \\
\hline American & 2.61 & 1.91 & 2.25 & 1.65 \\
\hline Cajun & 0.06 & 0.07 & 0.03 & 0.04 \\
\hline Chinese & 4.50 & 4.17 & 6.39 & 5.80 \\
\hline French & 0.61 & 0.44 & 1.48 & 1.34 \\
\hline German & 0.15 & 0.11 & 0.28 & 0.21 \\
\hline Greek & 0.16 & 0.15 & 0.30 & 0.26 \\
\hline Indian/Pakistan & 0.24 & 0.38 & 0.48 & 0.65 \\
\hline Italian & 2.79 & 2.53 & 4.21 & 3.52 \\
\hline Japanese & 1.43 & 1.75 & 1.97 & 2.40 \\
\hline Korean & 0.13 & 0.16 & 0.19 & 0.25 \\
\hline Lebanese & 0.02 & 0.02 & 0.02 & 0.02 \\
\hline Mexican & 4.42 & 5.10 & 8.24 & 8.45 \\
\hline Spanish & 0.07 & 0.06 & 0.04 & 0.05 \\
\hline Thai & 0.37 & 0.57 & 0.96 & 1.20 \\
\hline Vietnamese & 0.13 & 0.21 & 0.32 & 0.45 \\
\hline Other Asian & & & 0.30 & 0.35 \\
\hline Other Hispanic & & & 0.04 & 0.06 \\
\hline Other foreign (non-American) & & & 0.08 & 0.07 \\
\hline Ice cream and soft drink stands & 0.16 & 0.32 & 0.36 & 0.35 \\
\hline Concessionaire & 0.31 & 0.24 & 0.28 & 0.21 \\
\hline Frozen yogurt stand & 0.82 & 0.32 & 0.80 & 0.31 \\
\hline Ice cream stands & 1.69 & 1.37 & 1.73 & 1.36 \\
\hline Snow cone stand & 0.03 & 0.05 & 0.03 & 0.04 \\
\hline Soda fountain & 0.06 & 0.06 & 0.05 & 0.05 \\
\hline Soft drink stand & 0.04 & 0.04 & 0.03 & 0.03 \\
\hline Fast-food restaurants and stands & 1.92 & 1.31 & 2.21 & 1.60 \\
\hline Box lunch stand & 0.05 & 0.04 & 0.04 & 0.03 \\
\hline Carry-out only (except pizza) & 0.94 & 0.83 & 0.66 & 0.54 \\
\hline Chili stand & 0.02 & 0.02 & 0.01 & 0.01 \\
\hline Coffee shop & 1.66 & 3.12 & 2.34 & 3.63 \\
\hline Delicatessen & 1.43 & 1.08 & 1.34 & 0.98 \\
\hline Drive-in restaurant & 0.65 & 0.44 & 0.58 & 0.39 \\
\hline Fast-food, chain & 3.96 & 7.75 & 11.54 & 18.81 \\
\hline Fast-food, independent & 1.55 & 1.33 & 1.20 & 0.98 \\
\hline Food bars & 0.03 & 0.03 & 0.03 & 0.02 \\
\hline Grills & 0.49 & 0.89 & 0.46 & 0.58 \\
\hline Hamburger stand & 0.53 & 0.54 & 0.47 & 0.39 \\
\hline Hot dog stand & 0.35 & 0.31 & 0.32 & 0.29 \\
\hline Sandwiches shop & 2.30 & 2.24 & 1.81 & 1.58 \\
\hline Snack bar & 0.26 & 0.22 & 0.23 & 0.18 \\
\hline Snack shop & 0.13 & 0.10 & 0.11 & 0.09 \\
\hline Lunchrooms and cafeterias & 0.03 & 0.35 & 1.97 & 2.18 \\
\hline Automat & 0.01 & 0.01 & 0.01 & 0 \\
\hline Cafeteria & 0.42 & 0.30 & 0.36 & 0.23 \\
\hline Luncheonette & 0.07 & 0.05 & 0.07 & 0.05 \\
\hline Lunchroom & 0.01 & 0 & 0.01 & 0 \\
\hline Restaurant, lunch counter & 0.04 & 0.05 & 0.04 & 0.04 \\
\hline Family restaurants & 0.56 & 0.77 & 0.44 & 0.55 \\
\hline Family: chain & 0.97 & 1.09 & 1.19 & 1.13 \\
\hline Family: independent & 1.69 & 1.12 & 1.42 & 0.94 \\
\hline
\end{tabular}


Table 6 (continued)

\begin{tabular}{|c|c|c|c|c|}
\hline \multirow[t]{2}{*}{ SIC 8-digit industry } & \multicolumn{2}{|c|}{ Reported \% } & \multicolumn{2}{|c|}{ Recoded \% } \\
\hline & 1992 & 2002 & 1992 & 2002 \\
\hline Pizza restaurants & 3.68 & 4.3 & 4.23 & 4.01 \\
\hline Pizzeria, chain & 1.41 & 1.00 & 1.34 & 1.84 \\
\hline Pizzeria, independent & 1.40 & 0.76 & 1.29 & 0.68 \\
\hline Seafood restaurants & 1.13 & 0.89 & 1.16 & 0.96 \\
\hline Oyster bar & 0.01 & 0 & 0.01 & 0 \\
\hline Seafood shack & 0.04 & 0.11 & 0.03 & 0.08 \\
\hline Steak and barbecue restaurants & 0.04 & 0.05 & 0.17 & 0.13 \\
\hline Barbecue restaurant & 0.56 & 0.61 & 0.52 & 0.56 \\
\hline Steak restaurant & 0.78 & 0.61 & 0.53 & 0.40 \\
\hline \multicolumn{5}{|l|}{ Other } \\
\hline Buffet & 0.12 & 0.24 & 0.10 & 0.12 \\
\hline Café & 2.27 & 2.29 & 2.07 & 2.02 \\
\hline Caterers & 3.69 & 3.79 & 3.57 & 3.60 \\
\hline Chicken restaurant & 0.42 & 0.43 & 0.21 & 0.23 \\
\hline Commissary restaurant & 0.02 & 0.02 & 0.01 & 0.02 \\
\hline Contract food services & 0.18 & 0.18 & 0.10 & 0.11 \\
\hline Diner & 0.17 & 0.17 & 0.16 & 0.14 \\
\hline Dinner theater & 0.03 & 0.04 & 0.03 & 0.04 \\
\hline Health food restaurant & 0.09 & 0.08 & 0.09 & 0.07 \\
\hline Total & 100 & 100 & 100 & 100 \\
\hline Number of establishments & 41,000 & 47,608 & 41,000 & 47,608 \\
\hline
\end{tabular}

The sample is restricted to business establishments with SIC 4-digit industry 5812. The table reports the distribution of SIC 8-digit industries. Percentages shown for italicized entries are for restaurants that are not more finely classified. The recoding of establishments is based on the company name, as described in the text. For example, we can easily identify well-known chains (of fast-food, ice-cream places, and family restaurants). Ethnic restaurants of foreign ethnicity are identified based on the presence of foreign words in the company name

NETS

Cold Stone or Baskin Robbins (examples of ice cream places), and Denny's or Sizzler (examples of family restaurants). More important, we can also use the company name to identify ethnic restaurants that may have been misreported as generic eating places. We do so by searching for words included in the business name that point to a specific ethnicity (e.g., "Chinese" or "Mandarin," "Japanese" or "Tokyo," "Italy" or "Milan"), or for words from the foreign language of reference (e.g., "wok," "samurai," or "trattoria"). Our re-classification reduced by nearly half the share of unclassified places and substantially increased the share of restaurants of foreign ethnicities. We also separately identify three more categories of foreign ethnic restaurants: other Asian, other Hispanic, and other foreign ethnic restaurants.

Paralleling the analysis of the previous section, we are interested in exploring whether the presence of a large (and diverse) foreign-born population increases the choices of restaurants available to natives. First, we study the relationship between changes in the foreign-born share of the population and changes in the share of foreign ethnic restaurants, as in:

$$
\Delta \log \text { Ethnic_share }{ }_{a(c) t}=\eta+\delta \Delta \log (I / \text { Pop })_{a(c) t}+\phi \Delta \log \text { Pop }_{a(c) t}+\zeta a(c) t .
$$


Columns (1) and (2) of Table 7 present estimates of Eq. 5 for three different levels of aggregation: in Panel A we add up the number of restaurants and all population figures in tracts using the shopping weights defined in Eq. 2. In Panel B, we use shopping weights to define the growth of restaurants and

Table 7 Changes in the share of foreign ethnic restaurants and changes in the share of foreignborn population across bundles of Census tracts

\begin{tabular}{|c|c|c|c|c|}
\hline \multirow[t]{2}{*}{ Dependent variable } & \multicolumn{2}{|c|}{$\begin{array}{l}\text { Foreign ethnic restaurants/ } \\
\text { all eating places }\end{array}$} & \multicolumn{2}{|c|}{$\begin{array}{l}\text { Hispanic ethnic restaurants } \\
\text { all eating places }\end{array}$} \\
\hline & $\begin{array}{l}\text { Excluding } \\
\text { caterers } \\
\text { (1) }\end{array}$ & $\begin{array}{l}\text { Excluding } \\
\text { caterers, } \\
\text { fast food, } \\
\text { ice-cream } \\
\text { places } \\
\text { (2) }\end{array}$ & $\begin{array}{l}\text { Excluding } \\
\text { caterers } \\
\text { (3) }\end{array}$ & $\begin{array}{l}\text { Excluding } \\
\text { caterers, } \\
\text { fast food, } \\
\text { ice-cream } \\
\text { places } \\
\text { (4) }\end{array}$ \\
\hline
\end{tabular}

Panel A: Aggregation of all variables using weights from distribution of shopping trips
$\Delta \log$ foreign share
$0.180^{\mathrm{b}}$
$0.229^{\mathrm{a}}$
(0.066)
$(0.069)$

$\Delta \log$ foreign Hispanic share

$\begin{array}{cc}0.364^{\mathrm{a}} & 0.359^{\mathrm{a}} \\ (0.048) & (0.055) \\ -0.130 & -0.114 \\ (0.092) & (0.089) \\ 0.201 & 0.400^{\mathrm{b}} \\ (0.176) & (0.187)\end{array}$

$\Delta \log$ foreign non-Hispanic share

$\Delta \log$ population

$\begin{array}{ccc}-0.058 & 0.111 & 0.201 \\ (0.097) & (0.101) & (0.176)\end{array}$

$(0.187)$

Panel B: As in Panel A except foreign share defined using commuting weights
$\Delta \log$ foreign share
$0.440^{\mathrm{a}}$
$0.407^{\mathrm{a}}$
(0.108)
(0.116)

$\Delta \log$ foreign Hispanic share

$\begin{array}{cc}0.458^{\mathrm{a}} & 0.384^{\mathrm{a}} \\ (0.079) & (0.088) \\ -0.105 & -0.093 \\ (0.159) & (0.157) \\ 0.217 & 0.447^{\mathrm{b}} \\ (0.200) & (0.213)\end{array}$

$\Delta \log$ foreign non-Hispanic share

$\Delta \log$ population

$$
-0.087
$$

(0.088)

0.116

$(0.213)$

Panel C: Aggregation of variables across MSAs

$\Delta \log$ foreign share

$0.632^{\mathrm{a}}$

(0.094)

(0.089)

$0.584^{\mathrm{a}}$

$(0.086)$

$\Delta \log$ foreign Hispanic share

$\begin{array}{cc}0.361^{\mathrm{a}} & 0.274^{\mathrm{b}} \\ (0.093) & (0.102) \\ -0.050 & -0.012 \\ (0.145) & (0.146) \\ -0.378 & -0.068 \\ (0.344) & (0.374)\end{array}$

$\Delta \log$ foreign non-Hispanic share

$\begin{array}{rrrr}-0.857^{\mathrm{a}} & -0.645^{\mathrm{a}} & -0.378 & -0.068 \\ (0.233) & (0.203) & (0.344) & (0.374)\end{array}$

Dependent variable: Share of foreign ethnic or Hispanic restaurants. All variables are aggregated across Census tracts, with weights reflecting the distribution of shopping trips from the 2001 National Household Travel Survey (Panels A and B, except foreign share in Panel B defined using commuting-to-work weights), or across MSAs (Panel C). Observations: 6,807 tracts within MSAs (Panels A and B) and 25 MSAs (Panel C). Estimates are weighted by the 1992 number of restaurants, based on the same aggregation of tracts. Standard errors (in parentheses) in Panels A and $\mathrm{B}$ are clustered at the MSA level

a Significant at $1 \%$ level

b Significant at $5 \%$ level

NETS; Neighborhood Change Database and Summary Files (SF4), 1990 and 2000 Censuses 
of the total population, while we define the growth in the immigrant share of the population on areas centered on $c$ using commuting-to-work weights, to more accurately capture changes in the immigrant share of the local workforce. Finally, in Panel C, we aggregate all variables across the 25 MSAs in California, which may also better capture the labor market than using shopping weights. Regardless of the level of aggregation, we find that an increase in the foreignborn share of the population is associated with sizable increases in the share of ethnic restaurants. ${ }^{20}$

The effects are larger when defining the immigrant share in an area that more closely represents the size of the labor market (Panels B and C), suggesting that labor supply shifts may play an important role in the growth of ethnic restaurants. For example, in column (1), when we define the dependent variable as the ratio of foreign ethnic restaurants to all eating places (except caterers), we find that a $1 \%$ increase in the foreign-born share in the shopping area centered on $c$ is associated with a $0.18 \%$ increase in the share of ethnic restaurants in the same area, while a $1 \%$ increase in the foreign-born share in the commuting-to-work area centered on $c$ is associated with a $0.44 \%$ increase in the share of ethnic restaurants in the reach of consumers residing in tract $c$. The results are robust to an alternative definition of the share of ethnic restaurants - the ratio of foreign ethnic restaurants to all eating places excluding not only caterers but also fast-food and ice-cream places (column (2)).

If these positive associations are really an effect of immigration, then the ethnicity of the restaurants that "result" from immigration ought to be associated with the ethnicity of the immigrants. To test this prediction, we estimate the relationship between the growth in the share of Hispanic restaurants and the growth in both the share of Hispanic and non-Hispanic foreign-born in the population. ${ }^{21}$ We focus on Hispanic immigration because it was by far the largest immigrant inflow into California in our sample period. As shown in columns (3) and (4), we find that the within-ethnicity relationships are positive and significant, regardless of the level of aggregation, while the cross-ethnicity relationships are generally not significant, either economically or statistically (and are opposite-signed). In this analysis, though, it is only for the commuting weights (Panel B) that the positive relationship is stronger.

\footnotetext{
${ }^{20}$ Given that ethnic restaurants are predominantly stand-alone, we would likely similarly find that immigration is associated with increases in the share of stand-alone restaurants. However, because there may be many non-ethnic stand-alone restaurants that do not add to product diversity (think of another diner), evidence on how immigration affects the share of stand-alone restaurants is less informative about how immigration affects product diversity than is evidence on how immigration affects the ethnic composition of restaurants. (This is a reflection of the same problem we discussed earlier, with regard to the limitations of drawing conclusions about how immigration affects product diversity from evidence on how immigration affects the size distribution, and the chain versus stand-alone and big-box composition of the retail sector.)

${ }^{21}$ Hispanic restaurants are those of Mexican, Spanish, or other Hispanic ethnicity.
} 
Finally, we ask whether increasing variety of ethnic groups is associated with increasing variety of ethnic restaurants. While studying the correlates of the share of foreign-born in the population has the advantage of analyzing the effects of immigration using a similar approach to the small number of previous studies, it is not informative about "diversity" per se. Likewise, the share of ethnic non-American restaurants is not necessarily an appropriate measure of the variety of choices available to those who decide to eat out. To measure diversity, we construct Herfindahl-Hirschman indexes (HHI) of concentration for the ten ethnic nativity groups (indexed by $j$ ) that are separately identified at the Census tract level (US born individuals, and individuals born in Europe, Mexico, the Caribbean, Central America, South America, Canada, Asia, Africa, and Oceania), and for the eighteen types of ethnic restaurants (indexed by $m$ ) coded in the NETS or by us (listed in Table 6):

$$
\begin{aligned}
\mathrm{HHI}_{a(c)}^{\mathrm{pop}} & =\sum_{j=1}^{10}\left(\frac{\operatorname{Pop}_{j, a(c)}}{\sum_{j=1}^{10} \operatorname{Pop}_{j, a(c)}}\right)^{2} \text { and } \\
\mathrm{HHI}_{a(c)}^{\mathrm{eat}} & =\sum_{m=1}^{18}\left(\frac{\# \text { restaurants }_{m, a(c)}}{\sum_{m=1}^{18} \# \text { restaurants }_{m, a(c)}}\right)^{2} .
\end{aligned}
$$

Table 8 Changes in the Herfindahl-Hirschman index of concentration for ethnic restaurants and changes in the index of concentration for nativity groups

\begin{tabular}{llll}
\hline Aggregation & \multicolumn{2}{l}{$\begin{array}{l}\text { Census tract, weighted sum } \\
\text { of restaurants, and populations }\end{array}$} & Across MSAs \\
\cline { 2 - 4 } HH nativity index & Shopping weights & Commuting weights & \\
defined using & $(1)$ & $(2)$ & $(3)$ \\
\hline$\Delta$ HH index for & 0.042 & $0.161^{\mathrm{b}}$ & $0.316^{\mathrm{a}}$ \\
nativity groups & $(0.075)$ & $(0.060)$ & $(0.080)$ \\
$\Delta$ log population & 0.031 & $0.035^{\mathrm{c}}$ & $0.193^{\mathrm{a}}$ \\
& $(0.021)$ & $(0.019)$ & $(0.045)$ \\
\hline
\end{tabular}

Dependent variable: Changes in the Herfindahl-Hirschman index of concentration for ethnic restaurants, defined over 18 categories of ethnic restaurants (American, Cajun, Chinese, French, German, Greek, Indian/Pakistani, Italian, Japanese, Korean, Lebanese, Mexican, Spanish, Thai, Vietnamese, other Asian, other Hispanic, and other foreign). The independent variable capturing diversity is the change in the Herfindahl-Hirschman index of concentration for nativity groups, defined over 10 categories (US-born; born in Europe, Mexico, Caribbean countries, Central America, South America, Canada, Asia, Africa, or Oceania). All variables are aggregated across Census tracts, with weights reflecting the distribution of shopping trips from the 2001 National Household Travel Survey (columns (1) and (2), except the HH index for nativity groups in column (2) is defined using commuting-to-work weights) or across MSAs (column (3)). Observations: 6,807 Census tracts within MSAs (columns (1) and (2)) and 25 MSAs (column (3)). Estimates are weighted by the 1992 number of restaurants, based on the same aggregation of tracts. Standard errors (in parentheses) adjusted for heteroscedasticity and (in columns (1) and (2)) clustering across MSAs

a Significant at $1 \%$ level

b Significant at 5\% level

${ }^{c}$ Significant at $10 \%$ level

NETS; Neighborhood Change Database and Summary Files (SF4), 1990 and 2000 Censuses 
Table 8 reports the relationship between changes in the two indexes defined above, and shows evidence of a positive association between the ethnic diversity of the population and the ethnic diversity of restaurants, regardless of the level of aggregation. ${ }^{22}$ However, the positive association between population and restaurant diversity is only statistically significant, and is much stronger, when the diversity of the population (HHI ${ }^{\mathrm{pop}}$ ) is evaluated for areas that capture the extent of the relevant labor market (columns (2) and (3), using commuting-to-work weights and aggregation across MSAs, respectively), compared to defining the index to capture the diversity of the more limited pool of consumers (column (1)). This suggests that the more varied the composition of the population across nativity groups becomes-in terms of the workforcethe more varied is the composition of restaurants across ethnic lines, suggesting that the potential channel through which immigration delivers "consumption variety" is more likely to stem from a comparative advantage of immigrants in the production of ethnic food than from immigrants' consumption demands for ethnic food in restaurants (although we have little doubt that both channels are important.) This is consistent with the evidence that the restaurant labor force is strongly immigrant-intensive, as shown in Table 1, as well as the apparently greater effect of immigrant inflows in the restaurant sector than in retail, as shown in Table 2, which we interpreted as likely reflecting larger labor supply increases in the restaurant sector.

Notice that in our equations, we control for changes in the population. So, even if size per se creates diversity (Krugman 1979), we are explicitly testing for the increased variety that may arise from diversity in the population, which can clearly be enhanced by immigration; the coefficient on the HerfindahlHirschman index measures the relationship between diversity in the population and diversity in the types of restaurants once changes in the size of the population are held constant.

Of course, the mere presence of ethnically diverse restaurants does not mean that natives are better off. Although we do not attempt to estimate the actual welfare gains from diversity, a prerequisite for such gains would have to be that natives consume from the ethnic establishments that get created, rather than that these ethnic restaurants simply serve new immigrants from the corresponding ethnic group. Casual observation suggests that the clientele of ethnic restaurants is by no means limited to co-ethnics. And in fact a limited amount of research documents this. Liu and Jang (2009) collected data on customers of Chinese restaurants in a Midwestern US city and found that 60.2\% were Caucasian, while $32.0 \%$ were Asian. Josiam and Monteiro (2004) surveyed patrons of Indian restaurants in Minneapolis/St. Paul. Among their

\footnotetext{
${ }^{22}$ The indexes are both inversely related to variety, so this conclusion follows from the positive regression coefficients.
} 
respondents, $75 \%$ were classified as white American, and only $12 \%$ as South Asian. $^{23}$

For given elasticities of substitution of demand across different types of restaurant meals, another reason why natives would benefit from increased variety is through reduced prices. The lack of detailed data on prices at the local level prevents us from pursuing an approach along the lines of the estimation of Broda and Weinstein (2006) of the gains from trade.

\section{Conclusions}

Most of the debate on the economic consequences of immigration focuses on whether immigrants take jobs away from natives and reduce wages for US workers. In this paper, we direct attention instead to the effects of immigration on the composition of output, stemming from the fact that immigrants are consumers with potentially different demand characteristics and also may have a comparative advantage in the production of ethnic goods.

We look at these composition effects in a number of ways. First, we estimate the relationship between immigrant inflows and the size distribution and composition of business establishments. This analysis indicates that immigration is associated with fewer stand-alone retail stores, and a greater number of chains and in particular big-box retailers. This evidence would appear to contradict a diversity-enhancing effect of immigration, although we cannot draw firm conclusions because we do not have information on the types of goods that consumers buy at different stores.

Consequently, we focus more of our attention on the relationship between immigration and the ethnic diversity of restaurants, for which we can much more readily identify the types of products consumed by customers. The evidence indicates quite clearly that immigration is associated with increased ethnic diversity of restaurants, and labor supply shifts appear to play an important role in the growth of ethnic restaurants.

Our findings support the existence of some economic benefits of immigration that have rarely been documented in the literature. Although a statement about welfare would require a more structural approach, the diversity effects of immigration in the restaurant sector expand natives' consumption choices and, as such, are potentially welfare-enhancing. We find that these effects likely stem in part from comparative advantage of immigrants in the

\footnotetext{
${ }^{23}$ It would be ideal to know more about actual spending patterns of consumers. In his study of immigration to Israel, Lach (2007) infers something about spending patterns by looking at the association of immigrants from the former Soviet Union with prices for pork and vodka (given that their consumption demands for these products differ substantially from the rest of the population). But these are idiosyncratic cases. For the United States, the Consumer Expenditure Survey does not identify respondents who are immigrants, although it does identify Hispanic respondents. However, the survey does not identify spending at ethnic versus other restaurants, or spending on other goods that are strongly tied to ethnicity.
} 
production of ethnic food from their country of origin. On the other hand, with respect to the composition of the retail sector, one might plausibly view our evidence as suggesting that immigrant inflows increase the homogeneity rather than the diversity of consumption choices. This latter result may reflect the fact that immigrants do not have any particular comparative advantage in retail work, and, for that sector, their effect may act more through the demand side. Perhaps because of generally low incomes of immigrants, as well as sensitivity to prices, the demand effects of immigrants on the retail sector may do less to increase consumption diversity. Of course, low-income natives may gain more from growth of larger, big-box retailers that lower prices, even at the cost of standardization, than from increases in diversity of consumption choices, so that once we account for heterogeneity of the native population, the mapping from diversity to welfare is not necessarily straightforward.

Acknowledgements We are grateful to the University of California Labor and Employment Research Fund and the United Nations for research support, to Daria Burnes for outstanding research assistance, to Giuseppe Ragusa for help with programming, and to Albrecht Glitz, Saul Lach, Ken Small, Klaus Zimmermann, three anonymous referees, and seminar participants at UCI and the University of Milan, for helpful comments. Any views are our own, and not those of the University of California, Confindustria, the United Nations, or the Public Policy Institute of California. This paper circulated earlier with the title "Beyond Wages: The Effects of Immigration on the Scale and Composition of Output."

Open Access This article is distributed under the terms of the Creative Commons Attribution Noncommercial License which permits any noncommercial use, distribution, and reproduction in any medium, provided the original author(s) and source are credited.

\section{References}

Altonji J, Card D (1991) The effects of immigration on the labor market outcomes of less-skilled natives. In: Abowd J, Freeman RB (eds) Immigration, trade and the labor market. University of Chicago Press, Chicago, pp 201-234

Amuedo-Dorantes C, de la Rica S (2008) Complements or substitutes? Immigrant and native task specialization in Spain. CREAM Discussion Paper No. 16/08

Bodvarsson O, Van den Berg H (2006) Does immigration affect labor demand? Model and test. Res Labor Econ 24:135-166

Bodvarsson O, Van den Berg H, Lewer J (2008) Measuring immigration's effects on labor demand: a reexamination of the Mariel Boatlift. Labour Econ 15(4):560-574

Borjas G (2009) The analytics of the wage effect of immigration. NBER Working Paper No. 14796

Broda C, Weinstein D (2006) Globalization and the gains from variety. Q J Econ 121(2):541-585

Card D (2001) Immigrant inflows, native outflows, and the local labor market impacts of higher immigration. J Labor Econ 19(1):22-64

Card D, DiNardo J (2000) Do immigrant inflows lead to native outflows? Am Econ Rev Papers Proc 90(2):360-367

Chiswick CU (2009) The economic determinants of ethnic assimilation. J Popul Econ 22(4):859880

Cortes P (2008) The effect of low-skilled immigration on US prices: evidence from CPI data. J Polit Econ 116(3):381-422

Davis DR, Weinstein DE (2002) Technological superiority and the losses from migration. NBER Working Paper No. 8971

Feenstra R (1994) New product varieties and the measurement of international prices. Am Econ Rev 84(1):157-177 
Frattini T (2009) Immigration and prices in the UK. University of Milan Working Paper

Hatton TJ, Leigh A (2011) Immigrants assimilate as communities, not just as individuals. J Popul Econ 24(2):389-419

Jensen JB, Kletzer L (2010) Measuring tradable services and the task content of offshorable services jobs. In: Abraham K, Spletzer J, Harper M (eds) Labor in the new economy. University of Chicago Press, Chicago, pp 309-335

Josiam BM, Monteiro PA (2004) Tandoori tastes: perceptions of Indian restaurants in America. Int J Contemp Hosp Manag 16(1):18-26

Krugman P (1979) Increasing returns, monopolistic competition, and international trade. J Int Econ 9(4):469-479

Lach S (2007) Immigration and prices. J Polit Econ 115(4):548-587

Lazear E (2000) Diversity and immigration. In: Borjas G (ed) Issues in the economics of immigration. University of Chicago Press, Chicago, pp 117-142

Liu Y, Jang S (2009) Perceptions of Chinese Restaurants in the US: what affects customer satisfaction and behavioral intentions? Int J Hosp Manag 28(3):338-348

Neumark D, Kolko J (2010) Do enterprise zones create jobs? Evidence from California's enterprise zone program. J Urban Econ 68(1):1-19

Neumark D, Zhang J, Wall B (2007) Employment dynamics and business relocation: new evidence from the national establishment time series. Res Labor Econ 26:39-83

Ortega F, Peri G (2009) The causes and effects of international labor mobility: evidence from OECD Countries 1980-2005. NBER Working Paper No. 14833

Ottaviano G, Peri G (2006) The economic value of cultural diversity: evidence from US cities. Journal of Economic Geography 6(1):9-44

Ottaviano G, Peri G (2007) The effects of immigration on U.S. wages and rents: a general equilibrium approach. CEPR Discussion paper No. 6551

Ottaviano G, Peri G (2008) Immigration and national wages: clarifying the theory and the empirics. NBER Working Paper No. 14188

Peri G, Sparber C (2009) Task specialization, immigration, and wages. Am Econ J: Applied Econ 1(3):135-169

Saiz A (2003) Room in the kitchen for the melting pot: immigration and rental prices. Rev Econ Stat 85(3):502-521

Saiz A (2007) Immigration and housing rents. J Urban Econ 61(2):345-371

Sparber C (2008) A theory of racial diversity, segregation, and productivity. J Dev Econ 87(2):210226

Waldfogel J (2008) The median voter and the median consumer: local private goods and population composition. J Urban Econ 63(2):567-582 